\title{
The crustal structure of the Hawaiian Islands from marine multichannel seismic reflection data
}

\author{
B. BOSTON ${ }^{1 *}$, D. J. SHILLINGTON ${ }^{2}$, R. DUNN ${ }^{3}$, A. B. \\ WATTS $^{4}$, I. GREVEMEYER $^{5}$, L. GÓMEZ DE LA PEÑA ${ }^{5}$, G.

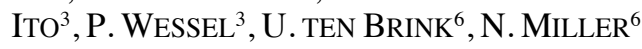 \\ ${ }^{1}$ Lamont-Doherty Earth Observatory of Columbia University, \\ 61 Route 9W, Palisades, NY 10964, USA \\ (*correspondence:brianb@1deo.columbia.edu) \\ ${ }^{2}$ Northern Arizona University, School of Earth and \\ Sustainability, 624 S. Knoles Drive, Flagstaff, AZ 86011, \\ USA \\ ${ }^{3}$ University of Hawaii, Department of Earth Sciences, 1680 \\ East-West Rd., Honolulu, HI 96822, USA \\ ${ }^{4}$ University of Oxford, Department of Earth Sciences, South \\ Parks Road, Oxford OX13AN, UK \\ ${ }^{5}$ GEOMAR Helmholtz Centre for Ocean Research Kiel, Kiel, \\ Germany \\ ${ }^{6}$ Woods Hole Coastal and Marine Science Center, US \\ Geological Survey, 384 Woods Hole Road, Woods Hole, \\ MA 02543, USA
}

The structure of the Hawaiian volcanic edifice and the Cretaceous oceanic crust on which it was built can illuminate controls on the formation and growth of the Hawaiian Chain. During September-October 2018, we used R/V Marcus G. Langseth to acquire deep-penetration, multichannel seismic reflection data across and along the Hawaiian Island Chain. For acquisition of this data, we used a nominal 6600-cu-in tuned air gun array and a 15-km-long hydrophone streamer cable. Two 500-km-long profiles cross the Hawaiian Chain west of the Big Island and west of Oahu; additional profiles along and around the islands characterize structure of the surrounding Pacific crust, including the Molokai Fracture Zone, and the flexure moats flanking the islands. Deep imaging of the Moho of Pacific oceanic crust indicates a spatial, reflectivity, and depth variations towards the islands and the Molokai Fracture Zone that may indicate the role of Hawaiian volcanism in modification of the oceanic crust. Profiles on the flanks near the Big Island and Oahu show volcanic spreading structures that sole into a decollement at the base of the volcanic edifice and top of oceanic crust. Newly imaged structures interpreted to arise from volcanic spreading are similar to features recognized off the eastern Big Island, suggesting common structures and processes over a large part of the Hawaiian Islands. These data show potential controls on formation and later gravitational collapse as the edifice continues to grow. 